\title{
Entrepreneurial orientation in long-lived family firms
}

\author{
Thomas Zellweger $\cdot$ Philipp Sieger
}

Accepted: 25 January 2010

(C) Springer Science+Business Media, LLC. 2010

\begin{abstract}
We apply a key construct from the entrepreneurship field, entrepreneurial orientation (EO), in the context of long-lived family firms. Our qualitative in-depth case studies show that a permanently high level of the five EO dimensions is not a necessary condition for long-term success, as traditional entrepreneurship and EO literature implicitly suggest. Rather, we claim that the level of EO is dynamically adapted over time and that the original EO scales (autonomy, innovativeness, risk taking, proactiveness, and competitive aggressiveness) do not sufficiently capture the full extent of entrepreneurial behaviors in long-lived family firms. Based on these considerations we suggest extending the existing EO scales to provide a more fine-grained depiction of firm-level corporate entrepreneurship in long-lived family firms.
\end{abstract}

Keywords Entrepreneurship - Entrepreneurial orientation · Family firm · Firm survival

JEL Classifications $\quad \mathrm{L} 21 \cdot \mathrm{L} 25 \cdot \mathrm{L} 26$

T. Zellweger $(\bowtie) \cdot$ P. Sieger

Center for Family Business, University of St. Gallen, Dufourstrasse 40a, 9000 St. Gallen, Switzerland

e-mail: thomas.zellweger@unisg.ch

P. Sieger

e-mail: philipp.sieger@unisg.ch

\section{Introduction}

A wide stream of corporate entrepreneurship literature proposes that entrepreneurial attitudes and behavior are crucial antecedents for a company's short- and long-term success (e.g., Dess et al. 2003; Zahra and Covin 1995; Zahra et al. 2000). Effective corporate entrepreneurship allows a firm to exploit its current competitive advantage while also exploring future opportunities and required competencies (Covin and Miles 1999; Kuratko et al. 2005; Schendel and Hitt 2007). In an environment of rapid change and shortened product and business model life cycles, future profit streams from existing operations are uncertain, requiring businesses to constantly seek new opportunities. Therefore, firms may benefit from adopting corporate entrepreneurship (Rauch et al. 2009).

Partly in contrast to these claims of the pivotal role of corporate entrepreneurship for organizational success, research on entrepreneurship in family firms that have survived and prospered for long periods of time is divided as to whether these organizations represent a context where entrepreneurship flourishes or is hampered (e.g., Naldi et al. 2007). Scholars argue that the particular culture and power structure found in many family firms may considerably influence the extent to which entrepreneurial activities are encouraged or hindered (Hall et al. 2001; Salvato 2004; Schein 1983; Zahra et al. 2004). Some propose that family firms present unique settings for entrepreneurship to flourish, for example, stewardship 
behavior (Eddleston and Kellermanns 2006), familyto-firm unity (Eddleston et al. 2008a), and long-term horizons (Zellweger 2007). In contrast to this positive perspective, Barringer and Bluedorn (1999) suggest that reliance on long-term planning horizons runs counter to the proactive nature of the entrepreneurial process, and that a long-term tenure is optimal for conservative and less entrepreneurial firms (Covin 1991; Covin and Slevin 1991). Studies suggest that family firms are endangered by, for example, strategic simplicity and inertia (Cabrera-Suarez et al. 2001; Miller 1983; Morris 1998). Moreover, Schulze et al. (2003) acknowledge the serious tensions that develop within the family firm between the need for change and stability, with entrepreneurship seen as an antidote to stability and strategic simplicity.

The finding that many family firms have managed to survive and flourish over long periods of time despite low levels of corporate entrepreneurship challenges traditional entrepreneurship wisdom. In light of these considerations and different findings in the literature, we see a need for further reflection on corporate entrepreneurship in the context of longlived family firms. We specifically examine entrepreneurial orientation (EO) and treat EO as a key construct of firm-level corporate entrepreneurship (Lumpkin and Dess 1996; Miller 1983).

We analyze corporate entrepreneurship in longlived family firms through three in-depth case studies of Swiss firms, between 80 and 175 years old. To touch upon the uniqueness of entrepreneurship in family firms originating from the systemic interactions between the individual, the family, and the firm (Habbershon et al. 2003), we interviewed 13 topechelon firm managers. Following precedent, we chose a qualitative methodology to encompass the different findings on corporate entrepreneurship in the family firm realm (Eisenhardt 1989). Using this methodology, we strive to overcome problems associated with the use of single-respondent survey data in entrepreneurship research (Zahra et al. 1999) and to address the general lack of attention to the lagged effect among the antecedents, performance outcomes, and different forms of corporate entrepreneurship (Dess et al. 2003).

By investigating EO in the context of long-lived family firms, we make several important contributions to the entrepreneurship and family business literatures. We not only shed additional light on the question of whether corporate entrepreneurship is a necessary condition for long-term success, but also add to the entrepreneurship literature by investigating the relationship between EO and performance (e.g., Rauch et al. 2009). Therefore, we build on and add to Zahra et al.'s (1999) reflection on equifinality, which suggests that organizations can utilize different orientations to reach the same objective and achieve the same outcome(s). Second, our analysis provides a more fine-grained perspective of EO in the context of family firms, which may help to explain the differing views in the literature about patterns of corporate entrepreneurship, such as about autonomy or risk taking (e.g., Nordqvist et al. 2008; Zahra 2005). Because we reach beyond the existing dimensions of EO and propose additional scales that have not been incorporated thus far, we follow the continuous calls of researchers to apply established concepts from the entrepreneurship field in the family business context in order to advance both fields (e.g., Chrisman et al. 2005; Chua et al. 2003; Hoy and Verser 1994).

Our paper is structured as follows. First, we provide theoretical foundations by giving an overview of corporate entrepreneurship research in the context of family firms. Second, we illustrate our case research methodology and describe the firms we examined. Third, we present our case study findings regarding the five EO dimensions and, where appropriate, develop propositions as analytical generalizations. Finally, we discuss our insights, examine limitations, and provide directions for future research.

\section{Theoretical foundations}

Corporate entrepreneurship is seen as critical to family firm success and survival across generations (Kellermanns and Eddleston 2006; Rogoff and Heck 2003; Salvato 2004). It refers to entrepreneurial activities within organizations that are designed to revitalize the company's business and to establish sustainable competitive advantages (cp. Kellermanns and Eddleston 2006; Kuratko et al. 2005; Zahra 1995, 1996). However, literature is discordant about the firm-level entrepreneurial tendencies of family firms. On one side, numerous researchers claim that family firms constitute an environment that is conducive to high levels of corporate entrepreneurship (Aldrich and Cliff 2003; McCann et al. 2001; Rogoff and Heck 
2003; Zahra et al. 2004). On the other side, scholars argue that family firms exhibit lower levels of entrepreneurial activities, as they are assumed to be risk averse (e.g., conservative and resistant to change and adaptation over time) (Allio 2004; Poza et al. 1997; Shepherd and Zahra 2003; Whiteside and Brown 1991). Recently, a number of articles have examined factors in family firms that affect corporate entrepreneurship, such as organizational culture (Habbershon and Pistrui 2002; Hall et al. 2001; Zahra et al. 2004), generational involvement (Kellermanns and Eddleston 2006), and stewardship characteristics (Eddleston et al. 2008a; Miller et al. 2008).

Also, a steadily growing stream of literature has investigated EO as a core concept of corporate entrepreneurship in the context of family firms (e.g., Martin and Lumpkin 2003; Nordqvist et al. 2008). EO refers to the strategy-making processes and styles of firms that engage in entrepreneurial activities (Lumpkin and Dess 1996, 2001). Since our research explores EO and its dimensions of autonomy, innovativeness, risk taking, proactiveness, and competitive aggressiveness (Lumpkin and Dess 1996), we deem it important to examine these dimensions and related research in the context of family businesses.

Autonomy as captured in the EO construct refers to the "independent action of an individual or a team in bringing forth an idea or a vision and carrying it through to completion" (Lumpkin and Dess 1996, p. 140), that is, the ability and will to be self-directed in the pursuit of opportunities. In an organizational context, it refers to actions taken free of stifling organizational constraints. Thus, even though factors such as resource availability, actions by competitive rivals, and internal organizational considerations may change the course of new-venture initiatives, these are not sufficient to extinguish the autonomous entrepreneurial processes that lead to new entry. Throughout the process, the organizational player remains free to act independently, to make key decisions, and to implement policy (Lumpkin and Dess 1996). In the context of family firms, Martin and Lumpkin (2003) show that the autonomy of family members of successive generations decreases. Family management limits its own autonomy by involving more people in decision-making processes and installing strong boards of directors. In a similar way, Spinelli and Hunt (2000) claim that a paternalistic leadership style is replaced by a more participative style in later generations. Nordqvist et al. (2008) view autonomy as important regarding long-term entrepreneurial performance and suggest considering autonomy as having both an external (autonomy from stakeholders such as banks, suppliers, customers, and financial markets) and an internal (empowering individuals and teams within an organization) dimension. Hence, literature seems to propose that, while autonomy may be seen as an important factor of corporate entrepreneurship, both internal and external autonomy need to be considered, whereas internal autonomy of family members of succeeding generations decreases.

Innovativeness refers to "a firm's tendency to engage in and support new ideas, novelty, experimentation, and creative processes that may result in new products, services, or technological processes" (Lumpkin and Dess 1996, p. 142). There is typically a continuum of innovativeness regarding both the scope and pace of innovation in products, markets, and technologies. Wealth is created when existing market structures are disrupted by introducing new goods or services, shifting resources away from existing firms and causing new firms to grow (Schumpeter 1942). The key to this cycle of activity is entrepreneurship: the competitive entry of innovative "new combinations" that propel the dynamic evolution of the economy (Schumpeter 1934). In family firms, innovativeness is regarded as a highly important dimension of EO for long-term performance, together with autonomy and proactiveness (Nordqvist et al. 2008). McCann et al. (2001) find that younger and smaller family firms are more likely to be innovative than older, larger family firms. Furthermore, innovativeness is described as having greater potential for high performance, if it is driven by comprehensive strategic decision-making and long-term orientation (Eddleston et al. 2008a; McCann et al. 2001).

Risk taking, in turn, refers to "the degree to which managers are willing to make large and risky resource commitments-i.e., those which have a reasonable chance of costly failures" (Miller and Friesen 1978, p. 932). Recent research draws a more fine-grained picture about the risk taking propensity of family firms (e.g., Gomez-Mejia et al. 2007; Morck and Yeung 2003). Gomez-Mejia et al. (2007) find that family firms take decisions based on reference points. To protect socio-emotional wealth, family firms accept risk to their performance and, at the same time, avoid decisions that aggravate risk. Naldi et al. (2007) report 
that risk taking in family firms is positively associated with proactiveness and innovation and negatively with financial performance. Zahra (2005) finds that chief executive officer (CEO)-founder duality has no effect on risk taking, while long $\mathrm{CEO}$ tenure has a negative effect. Nordqvist et al. (2008) find that in family firms "there are less signs of risk-taking and competitive aggressiveness in comparison to proactiveness, innovativeness and autonomy" (p. 108). Martin and Lumpkin (2003) find partial support for their claim that family firms are more risk averse in later generations. Thus, literature on risk taking in family firms is divided on whether firms are risk-averse or risk-inclined organizations. Moreover, the validity of research is undermined by inconsistencies regarding the definition and measurement of risk taking. Martin and Lumpkin (2003) investigate risk in terms of investing personal assets and making loans to the business, tolerance of debt, and the importance of increasing profitability. Other authors investigate willingness to innovate (Benson 1991), variation of performance outcomes (Gomez-Mejia et al. 2007), or debt levels (Mishra and McConaughy 1999). In light of these inconsistencies in the literature, an assessment of family firms' risk aversion is problematic.

Proactiveness refers to a firm's efforts to seize new opportunities. Lumpkin and Dess (2001, p. 431) define proactiveness as an "opportunity seeking, forward-looking perspective involving introducing new products or services ahead of the competition and acting in anticipation of future demand to create change and shape the environment." It involves not only recognizing changes, but also being willing to act on those insights ahead of the competition (Dess and Lumpkin 2005). Similarly, Stevenson and Jarillo (1990) conceptualize proactiveness as the organizational pursuit of favorable business opportunities. Proactive behavior can lead to first-mover advantages and higher economic profits (Lieberman and Montgomery 1988). According to Kreiser et al. (2002), the dimension of proactiveness has received less attention from entrepreneurship researchers than, for example, the dimensions of innovativeness and risk taking. In the context of family firms, proactiveness is regarded as more important, together with autonomy and innovativeness (Nordqvist et al. 2008). These authors argue that, when the historical path/new path, independence/dependence, and informality/formality dualities are kept taut, family firms are freer to act independently and proactively, thereby avoiding risk taking and competitive aggressiveness. Martin and Lumpkin (2003) find that proactiveness does not seem to be a consistent predictor of family firm success, and they were not able to prove that proactiveness decreases with later generations. In sum, the literature presents different findings regarding the relevance of this entrepreneurship dimension.

Finally, competitive aggressiveness refers to "a firm's propensity to directly and intensely challenge its competitors to achieve entry or improve position, that is, to outperform industry rivals in the marketplace" (Lumpkin and Dess 1996, p. 148). Competitive aggressiveness can be reactive as well. For instance, a new entry that is an imitation of an existing product or service would be considered entrepreneurial if the move implies an aggressive, head-to-head confrontation in the market. According to Lumpkin and Dess (1996), competitive aggressiveness also embraces nontraditional methods of competition, such as new types of distribution or marketing. Martin and Lumpkin (2003) find that, as later generations assume control and focus more on value and profitability than on directly challenging competitors to gain market share, the level of competitive aggressiveness decreases. In a qualitative study, Nordqvist et al. (2008) suggest that few of their interviewees choose to take on a competitor head-on (Lumpkin and Dess 1996), instead competing with little consideration of competitors' actions. This seems to suggest that an essential feature of entrepreneurial behavior, competitive aggressiveness, is of lower relevance in the context of family firms.

In sum, research provides ambiguous findings as to whether the family firm context fosters or hampers corporate entrepreneurship. Also, scholars propose considering certain EO dimensions separately (e.g., internal and external autonomy; Nordqvist et al. 2008) to capture the full extent of entrepreneurial postures, thus questioning the applicability of the construct in the family firm context. Moreover, literature measures certain EO scales inconsistently (e.g., risk taking) (Zahra 2005). In light of such concerns about levels and patterns of corporate entrepreneurship in long-lived family firms, we see a need to revisit the underlying assumptions of both corporate entrepreneurship and family business research as a first step toward a better understanding of corporate entrepreneurship in this context. 
Therefore, we follow Low and MacMillan's (1988) advice that the entrepreneurship field will be better served if the issue of theoretical perspective is addressed directly and if assumptions are made explicit.

Considering the implicit assumption of entrepreneurship research we suggest that the entrepreneurship field has generally considered younger and often fast-growing firms, stressed the dynamic context in which firms are embedded, and often focused on owner-managed firms in the first generation, which have a short-term horizon (Gartner 1990; Zahra and Sharma 2004). Success is often determined in terms of growth or financial performance and the harvesting of entrepreneurial opportunities. Despite the assertion that families may assist a firm's start-up phase by investing personal assets (Aldrich 1999; Chrisman et al. 2002), the family aspect has been widely neglected in traditional entrepreneurship research.

In contrast, we see family business research embedded mainly in the context of established, larger, and often multigenerational firms in mature industries, with long planning horizons and strong emphasis on family aspects and relationships across all types of managerial activities (Hoy 1992; Hoy and Verser 1994). Success is often defined in broader terms, including nonfinancial performance or the survival of the firm. As the focus is rather on family relationships, entrepreneurial behavior of firms is widely neglected. For a better illustration, these aspects of both entrepreneurship and family business literature are summarized in Table 1, which provides a prototypical overview of these two perspectives, each containing specific assumptions about the type of firm, industry, ownership, resource challenge, planning horizon, measures of performance, and corresponding research focus.

The inherent danger of this artificial dichotomization is that a certain behavior (e.g., entrepreneurial) is applied or misunderstood as the normative concept of the "right" behavior in any context. Through the theoretical lens of corporate entrepreneurship, a family firm navigating in a stable competitive context might be considered as nonentrepreneurial, thereby lacking a fundamental precondition for its long-term success. However, there are concerns in entrepreneurship literature about equifinality, which suggests that organizations can utilize different orientations to
Table 1 The traditional perspectives of entrepreneurship and family business literature

Based on Hoy and Verser (1994), Hoy (1992), Gartner (1990), Brockhaus (1994), Sharma (2004), and Zahra and Sharma (2004)

\begin{tabular}{ll}
\hline Entrepreneurship literature & Family business literature \\
\hline $\begin{array}{l}\text { Type of firm } \\
\text { Young, newly created, often fast-growing, } \\
\text { small and mid-sized firms }\end{array}$ & $\begin{array}{c}\text { Established, traditional, often multigenerational, } \\
\text { and larger firms }\end{array}$ \\
$\begin{array}{l}\text { Type of industry } \\
\text { Growing and dynamic industries } \\
\text { and markets }\end{array}$ & Mature industries and saturated markets \\
$\begin{array}{l}\text { Type of ownership } \\
\text { Owner-managed/first-generation } \\
\text { partnerships }\end{array}$ & \\
$\begin{array}{l}\text { Resource challenge } \\
\text { Adding resources to establish an } \\
\text { organization in the competitive } \\
\text { environment }\end{array}$ & $\begin{array}{c}\text { Reconfiguring and shedding resources to continue } \\
\text { and readjust an organization in the competitive }\end{array}$ \\
$\begin{array}{l}\text { Short } \\
\text { Measures of success and performance }\end{array}$ & $\begin{array}{c}\text { Lonironment } \\
\text { Financial performance } \\
\text { Taking advantage of opportunities in the } \\
\text { market }\end{array}$ \\
$\begin{array}{l}\text { Main focus of research } \\
\text { Entrepreneurial behavior (family } \\
\text { relationships are widely neglected) }\end{array}$ & $\begin{array}{c}\text { Meeting a mixed goal set of financial and } \\
\text { nonfinancial performance dimensions }\end{array}$ \\
\hline
\end{tabular}


reach the same objective (Zahra et al. 1999). Jennings and Seaman (1994) propose that performance differences may not exist between entrepreneurial and conservative firms, making the implicit assumption that first-mover firms that incur the highest risk and costs for innovative activities would always be rewarded for doing so (Zahra et al. 1999).

Considering these reflections, we now describe our methodology through which we hope to gain additional insights into the levels and patterns of corporate entrepreneurship in long-lived family firms.

\section{Research design}

Our study relies on case study methodology. Eisenhardt (1989) advocates case study research when little is known about a phenomenon, current perspectives seem inadequate due to a lack of empirical substantiation or conflict with each other, or "when freshness in perspective to an already researched topic" is needed (Eisenhardt 1989, p. 548). Punch (2005) states that case study research is suitable in situations where "knowledge is shallow, fragmentary, incomplete or non-existent" (p. 147). Based on the previous literature review and theoretical considerations, we regard the current status of research as disparate and knowledge as fragmented. Thus, we conclude that a case study approach is legitimate for the purpose of this study. Consequently, we investigate the five EO dimensions exploratively and, where appropriate, develop propositions ex post. This methodology is supported by Punch (2005) and Yin (1994), who state that one of the goals of explorative case studies is to develop pertinent hypotheses and propositions for further inquiry.

The present paper is based on three in-depth qualitative case studies conducted in Switzerland in 2006 and 2007 as part of the Successful Transgenerational Entrepreneurship Practices (STEP) research project. $^{1}$ The companies are Health Pharma AG, Taste SA, and Technics AG. Table 2 provides detailed information about the three cases as well as the selection criteria applied. Our case study approach corresponds to the guidelines of the STEP

\footnotetext{
${ }^{1}$ STEP is a worldwide research project, investigating entrepreneurship in the context of multigeneration family firms; see www.stepproject.org.
}

research project and has been applied in other studies investigating $\mathrm{EO}$ in a qualitative manner (e.g., Nordqvist et al. 2008).

The interview guideline, which was developed by a team of three researchers familiar with both $\mathrm{EO}$ and family business research, contains questions pertaining to all five EO dimensions. Additional descriptive statements or questions helped researchers choose the issues to be addressed (e.g., "how and why family influence and/or involvement impacts a firm's innovativeness"). In each company, two interviewers conducted four or five semistructured interviews with both family and nonfamily members in top-echelon positions [e.g., CEO, chief financial officer (CFO), head of marketing, etc.]. Each interview lasted between 60 and $90 \mathrm{~min}$. We asked the respondents to touch upon both EO at the firm level and specific family involvement. We audiotaped all interviews and gathered secondary data from company websites, annual reports, press releases, and company documents to map out major strategic entrepreneurial actions, to describe important contingencies (industry, tax structure, or environment), to document relevant outcomes, and to accomplish "triangulation" (i.e., corroborate relevant information gathered through the interviews).

The interviews were then transcribed and coded by a $\mathrm{PhD}$ student who, although not involved in the interviews, was familiar with both EO and family business literature and with case writing. We chose a third person for this part of our study to further increase the reliability of our findings and interpretations and to ensure divergent perspectives (Eisenhardt 1989). We did not use specific coding software because the number of interviews was limited and their length was not excessive. As the interviews were conducted on a semistructured basis, we could rapidly identify and access defined constructs under consideration.

The coding led to three case study protocols, each with a length of about 30 pages. $^{2}$ These protocols were enriched with several tables, highlighting the family's and the firm's history and evolution, financials of the company, and an overview table of the five EO dimensions, including related statements of the interviewees. This helped us to become intimately

\footnotetext{
2 These case study protocols are available on request from the authors.
} 
Table 2 Overview of selected cases

\begin{tabular}{|c|c|c|c|}
\hline Company name & Health Pharma AG & Taste SA & Technics AG \\
\hline Industry & Pharmaceuticals & Consumer goods & Printing and filtration \\
\hline $\begin{array}{l}\text { Employees in } \\
2007\end{array}$ & 340 & 175 & 2,000 \\
\hline Company age & 140 years & 80 years & 175 years \\
\hline $\begin{array}{l}\text { Annual sales } \\
2007\end{array}$ & 60 million Euros & 30 million Euros & 200 million Euros \\
\hline $\begin{array}{l}\text { Export } \\
\text { orientation }\end{array}$ & $5 \%$ of sales & $30 \%$ of sales & $\begin{array}{l}\text { Subsidiaries in } 21 \text { countries, } \\
\text { representations in } 75 \text { countries }\end{array}$ \\
\hline Ownership & $\begin{array}{l}\text { 100\% family owned } \\
\text { (two branches, } 51 \%: 49 \% \text { ) }\end{array}$ & $\begin{array}{l}100 \% \text { family owned by Taste } \\
\text { brothers }(51 \%: 49 \%)\end{array}$ & $\begin{array}{l}\text { Owned by } 150 \text { descendants of the nine } \\
\text { founding families }+ \text { a few managers } \\
\text { (ca. } 95 \% \text { family ownership) }\end{array}$ \\
\hline $\begin{array}{l}\text { Family } \\
\text { involvement }\end{array}$ & $\begin{array}{l}\text { CEO and CFO, members } \\
\text { of the supervisory board }\end{array}$ & $\mathrm{CEO}$, director of marketing & $\begin{array}{l}\text { CEO and members of the supervisory } \\
\text { board }\end{array}$ \\
\hline No. of interviews & 5 & 4 & 4 \\
\hline $\begin{array}{l}\text { Position and } \\
\text { status of } \\
\text { interviewees }\end{array}$ & $\begin{array}{l}\text { CEO (family), CFO (family), head } \\
\text { of marketing, head of production, } \\
\text { president supervisory board }\end{array}$ & $\begin{array}{l}\text { CEO (family), head of marketing } \\
\text { (family), export director, chief } \\
\text { of production }\end{array}$ & $\begin{array}{l}\text { CEO (family), CFO, president } \\
\text { supervisory board, member } \\
\text { supervisory board (family) }\end{array}$ \\
\hline $\begin{array}{l}\text { Family } \\
\text { generation }\end{array}$ & 5 th & $3 r d$ & 7 th \\
\hline
\end{tabular}

Names changed for anonymity purposes

familiar with each case and enabled unique patterns to emerge before cross-case comparison (Eisenhardt 1989). By integrating the information gained through the interviews with information gained through secondary materials, we measured EO using a combination of firm behavior and managerial perceptions (Lyon et al. 2000). Following Yin (1998), the case study protocols were organized by the sequence of topics in the interviews. The case study protocols and the audiotapes were then sent to the two interviewers, who independently reviewed and adapted the protocols.

Each of the three researchers independently assessed the levels of the five EO dimensions at the point of investigation for every company using a nine-point scale ranging from 1 (low) to 9 (high). To avoid overspecification, we formed three categories: low (rating 1-3), medium (rating 4-6), and high (rating 7-9). This resulted in a graphical illustration of all five EO dimensions for every company by each researcher (nine total EO profiles). The three researchers then met, discussed the case study protocols, and agreed on a final version, which varied only marginally from the original version. After comparing identified EO patterns, we agreed upon one profile for each firm, reflecting our shared understanding. Of the 45 judgments of EO levels ( 3 researchers $\times 3$ cases $\times 5$ dimensions), we reached initial agreement in 42 out of 45 cases $(>90 \%)$; the rare disagreements were resolved, since they referred to adjacent classifications. Consequently, we consider that interrater reliability was not a main concern in our study. In addition, researchers together considered possible shortcomings and extensions of the existing EO measures, resulting in a refined conceptual grid on EO in the context of long-lived family firms (cp. Denzin and Lincoln 2000).

As a further test of the reliability of our findings, and in line with suggestions by Denzin and Lincoln (2000), we performed a member check by crosschecking our work with managers' perceptions. The interviewees had the opportunity to read and comment on the case study protocols and our assessment of the EO patterns of their companies. This procedure 
not only is in accordance with Yin's (1994) recommendation about construct validity, but also increases the study's reliability. The interviewees had only minor comments, which were incorporated into our analysis.

\section{Results}

In this section, we present our case-based findings regarding the five dimensions of EO. Figure 1 provides an overview of the levels and patterns of EO in our family firms.

\subsection{Autonomy}

As outlined previously, there are arguments that in the context of family firms the autonomy of successive generations decreases (Martin and Lumpkin 2003). Nordqvist et al. (2008) suggest considering autonomy as having both an external and an internal dimension. External autonomy refers to independence from stakeholders such as banks, suppliers, customers, and financial markets. Internal autonomy is related to empowering individuals and teams within an organization. Nordqvist et al. (2008) suggest that, over time, family firms may increase internal autonomy of their employees.

We find a clear differentiation between internal and external autonomy. Our family and nonfamily interviewees agree on the importance of internal autonomy, understood as empowering individuals and teams, as a driver of entrepreneurial activity. In-depth interviews reveal that the third Taste generation and the fifth Health generation successfully managed to overcome the more patriarchal and authoritarian leadership style of their parents (fathers). The nonfamily managers of Taste SA feel that open communication in the management team and the new management and leadership style are positive developments. Internal autonomy at the workplace is therefore a more recent management practice, which is adopted by later generations and is represented by the presence of more nonfamily managers. However, more emphasis has always been, and is still, placed on external autonomy, meaning independence from external stakeholders. The first and foremost goal of all examined companies is to secure their independence in terms of external autonomy. According to
Jean Taste, shareholder and marketing director of Taste SA: "One of our main goals is not to endanger the firm's independence and family control." As Regula Blinkli, nonfamily marketing director of Health AG, points out: "The wish for autonomy on the company level has always been a major driving force in the development of the company." Similarly, Karl Melber, nonfamily CFO of Technics AG, stresses that: "Independence from external parties has always been very important."

Our interviewees also suggest that external autonomy on the firm level may provide owners and managers with the freedom to implement a unique strategy that does not have to satisfy short-termoriented shareholder demands, hence increasing internal autonomy. A few years ago, the 150 family shareholders of Technics AG chose not to open its shareholder structure to the public for external and internal autonomy reasons. Managers of Technics AG consider external autonomy of the organization as a means to create internal autonomy of managers, thus generating further entrepreneurial development.

Accordingly, our scoring of EO levels shows high levels of external and medium levels of internal autonomy across all firms (Fig. 1). We thus support the notion of Martin and Lumpkin (2003) and Nordqvist et al. (2008) that internal autonomy increases as later generations assume control of the business and shift to a more participative leadership style. In agreement with Nordqvist et al. (2008), we also find a clear distinction between external and internal autonomy, whereas external autonomy remains highly relevant over time across all firms. Accordingly, we propose that internal autonomy, at least retrospectively, cannot serve as an explanation for the continuing success of these firms. The constant presence of external autonomy better explains this success. In sum, we offer the following proposition:

Proposition 1 Long-lived family firms display constantly high levels of external autonomy across time, whereas internal autonomy increases as later family generations join the firm.

\subsection{Innovativeness}

Innovativeness is regarded as a highly important dimension of EO for the long-term performance of 
Fig. 1 Refined EO profiles of the three companies

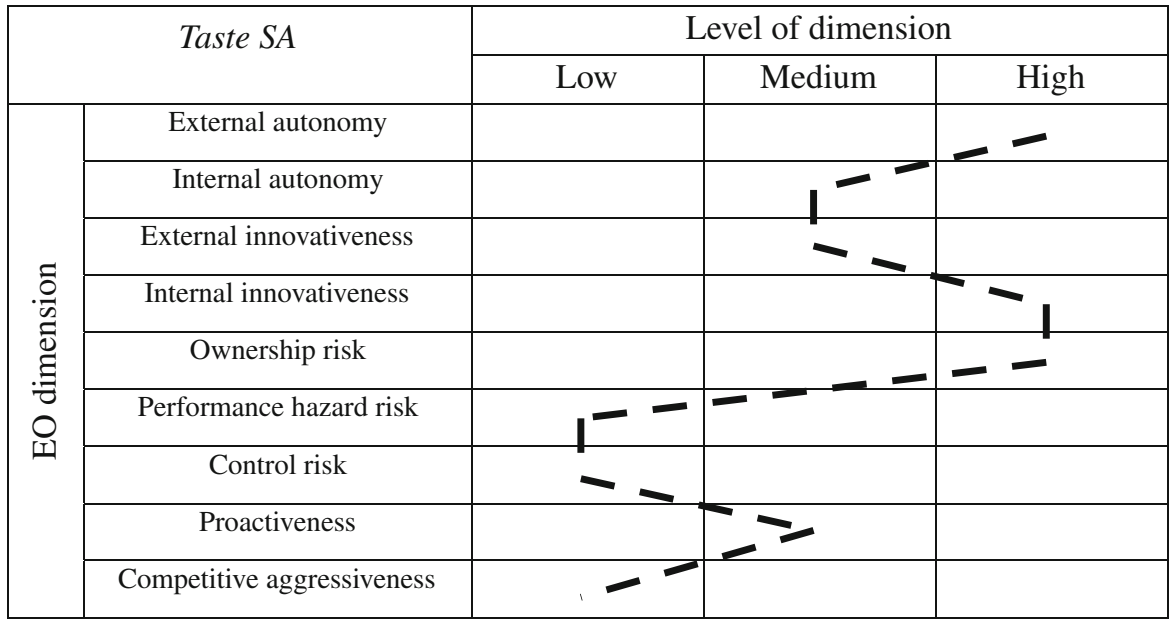

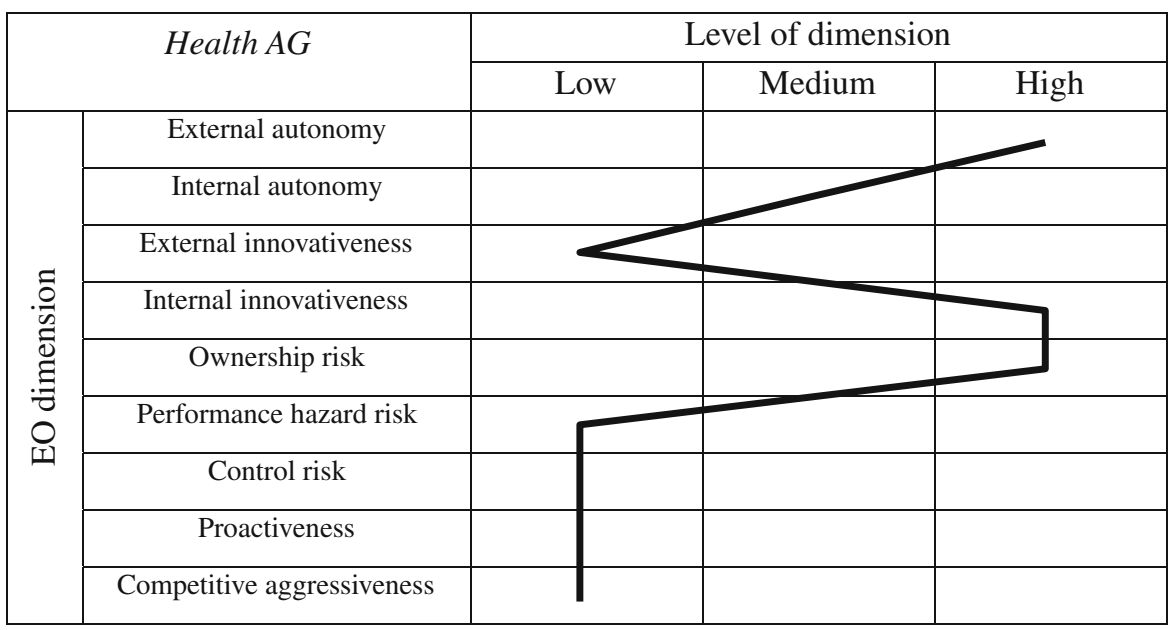

\begin{tabular}{|c|c|c|c|c|}
\hline & \multirow{2}{*}{ Technics $A G$} & \multicolumn{3}{|c|}{ Level of dimension } \\
\hline & & Low & Medium & High \\
\hline \multirow{9}{*}{$\begin{array}{l}\frac{\tilde{0}}{0} \\
\frac{0}{0} \\
0 \\
0 \\
0 \\
0\end{array}$} & External autonomy & & & \\
\hline & Internal autonomy & & & \\
\hline & External innovativeness & & & \\
\hline & Internal innovativeness & & & \\
\hline & Ownership risk & & & . \\
\hline & Performance hazard risk & & & \\
\hline & Control risk & : & & \\
\hline & Proactiveness & - & & \\
\hline & Competitive aggressiveness & $\bullet$ & & \\
\hline
\end{tabular}


family firms (Eddleston et al. 2008b). McCann et al. (2001) find that younger and smaller firms are more likely to be innovative than older and larger firms. Furthermore, innovativeness is described as leading to greater potential for high performance, as it is driven by comprehensive strategic decision-making and long-term orientation (Eddleston et al. 2008b; McCann et al. 2001). Specific patterns of innovativeness seem to exist. According to Frank Taste, CEO of Taste SA, "Innovativeness is truly important since the introduction of our top-selling chocolate bar in the 1940s was a true innovation. But customers are slow in accepting new products and often show a high preference for a product they had known for years. Consequently, the introduction of new products and the entrance to new markets has been rather slow. Still, the company earns the largest part of its sales volume with the chocolate bar."

Similarly, Technics AG did not constantly display high levels of innovativeness over its nearly 180 years of existence. Revolutionary phases, sometimes with intervals of up to three decades, were interspersed with evolutionary and incremental innovation phases. As the family CEO of Technics AG, a company that is active in an industry with proven manufacturing standards, states: "Big innovations come in waves and always have to be digested." Health AG managed to generate sales of roughly 60 million Euros in a highly regulated niche market with little innovation in new products or development of new markets. According to the family CEO, Mrs. Julia Health, the firm is "not very innovation-driven when we look at new products, production processes, or technology." Innovativeness is restricted by family heritage to a certain extent (e.g., products carrying the name of the former family CEO). Change occurs slowly and over time. When Regula Blinkli, nonfamily Head of Marketing, asks "why is this so?", the answer often is: "This has always been like that, it comes from the former family CEO."

Beyond fluctuating levels across time, we identify a distinct pattern of innovativeness that is not captured by the traditional EO construct. We find high levels of innovativeness within these firms, in forms that are less visible from the outside and are not represented by "the new" in terms of products, services, or technological processes (i.e., external innovation). However, these firms have made improvements that are innovative and value-generating through renewal from within (i.e., internal innovation). As Health AG's CEO mentions: "Innovation rather comes from the inside; for example, the introduction of new management systems and structures than from the product or production side." More specifically, in recent years the firms under investigation have concentrated on implementing new management techniques such as fostering internal improvement processes or financial management systems (Health AG), introducing a balanced and effective governance structure that represents the owning families with a committed management board (Technics AG), or implementing an umbrella brand strategy (Taste SA). This focus on internal innovativeness could be explained by the discretionary scope of action for the owner-managers of these firms. Due to higher degrees of internal freedom and lower degrees of freedom in an industrial context dominated by large multinationals, internal changes were more easily conceivable than changes that immediately affect the marketplace. The researchers' independent scoring of internal and external innovativeness reveals medium to low levels of external innovativeness (new products, markets, and technological processes) and medium to high levels of internal innovativeness (new managerial processes, structures, and management systems) (Fig. 1).

By connecting the two insights on fluctuating levels of innovativeness across time and the differentiation between internal and external dimensions, we find that the family-dominated life cycle of management and ownership structure has an impact on the variation of both types of innovativeness. Within Taste SA and Health AG, we find high degrees of internal innovativeness during the first years after the transfer of control from one family generation to the next. After having assumed control from their father, the Taste brothers first built a management team and redefined leadership structures, thereby focusing on internal innovativeness. Once these changes were in place, their focus shifted to external innovativeness in terms of launching new products. Similarly, the family managers of Health AG implemented a management information system to monitor the actual financial performance of the firm before focusing on external innovativeness. In both cases, the preceding generations' management style was highly personalized. Therefore, the later generation assuming control first had to resolve issues surrounding internal reorganization and innovativeness of decision-making, 
leadership team, and style. Only after these challenges had been met could external product and market innovations be considered.

Thus, we add two key insights to the innovativeness dimension within EO in the context of long-lived family firms. First, to capture the full extent of entrepreneurial behavior, innovativeness should differentiate between an external and an internal perspective. Second, the level of both external and internal innovativeness varies continuously over time and is strongly affected by generational changes. Accordingly, we develop the following propositions:

Proposition 2a The level of external innovativeness (new markets, products, and technological services) and internal innovativeness (new processes, structures, and management systems) in long-lived family firms fluctuates across time.

Proposition 2b Generational changes positively impact both forms of innovativeness.

\subsection{Risk taking}

As outlined in our theory section, ambiguous findings about levels of risk taking in family firms may be related to inconsistent use of definitions and measures (for an overview refer to, e.g., Gomez-Mejia et al. 2007; Morck and Yeung 2003). Martin and Lumpkin (2003) investigate risk in terms of investing personal assets and making loans to the business, tolerance of debt, and the importance of increasing profitability. Other authors investigate willingness to innovate (Benson 1991), variation of performance outcomes (Gomez-Mejia et al. 2007), or debt levels (leverage) as a measure of control risk (Mishra and McConaughy 1999). Drawing on this confusion, Zahra (2005) claims that a broader definition of risk taking is needed, as it is a complex construct with presumably multiple dimensions.

Our findings shed further light on the intriguing issue of risk taking in family firms. Prima facie, our family firms are risk averse when measured in terms of leverage. The average share of equity from total assets is $75 \%$ in our firms. Across generations, all firms have been very "cautious with debt capital," according to the family CFO of Health AG. To avoid the risk of losing control over the company (control risk), they financed investments with their own cash flow (Mishra and McConaughy 1999).
Furthermore, the level of performance hazard risk, defined as the risk of organizational failure induced by business decisions, is low. This type of risk is measured through the probability of organizational failure or threats to survival (Hoskisson et al. 1991). We find that our family firms did take what Frank Taste labeled "calculated business risks," that is, balancing the performance hazard risks associated with management decisions against existing solutions so that a project's failure would not threaten the firm's survival. As the president of the supervisory board of Technics AG states: "We will only engage in projects that do not endanger the company as a whole." In a similar way, the family CFO of Health AG claims that making a major step forward is difficult, "as only small risks are taken and only low levels of debt capital accepted." A member of Heath's supervisory board states that "it is better to muddle through with an existing concept without making large resource commitments. Being active in niches with amortized machinery is typical for companies like ours."

In all cases, the family's background has a negative impact on taking decisions that could increase performance hazard risk. This may be understood in light of increased ownership risk, understood as investing most of one's personal wealth in only one or a few assets with no or only limited diversification. All interviewed family owners had assumed a high ownership stake in the family firm. According to the CFO of Technics AG: "The family shareholders prefer a stable dividend. We need to assure the dividend flow at any time, since there are family members for which the investment in our firm represents the largest part of their wealth and their pension fund."

Accordingly, our cases reveal a nuanced pattern of risk taking once we differentiate between control risk (measured as leverage levels), performance hazard risk (measured as probability of organizational failure), and ownership risk (measured as owners holding undiversified assets). The researchers' independent scoring reveals that all firms displayed higher levels of ownership risk and lower levels of both performance hazard and control risk (Fig. 1). Thus:

Proposition 3 Long-lived family firms display higher levels of ownership risk and lower levels of both performance hazard and control risk. 


\subsection{Proactiveness}

Inconsistent findings exist in the literature about the relevance of proactiveness in the context of family firms. Nordqvist et al. (2008) argue that, when the historical path/new path, independence/dependence, and informality/formality dualities are kept taut, family firms are more inclined to be proactive. In contrast, Martin and Lumpkin (2003) find that proactiveness does not seem to be a consistent predictor of family firm success.

In our case studies, long-lived family firms displayed low to moderate levels of proactiveness (Fig. 1). Specifically, we find that, in contrast to the central role entrepreneurship literature assigns to proactiveness, the companies in our study follow an evolutionary rather than a proactive path. A member of the supervisory board of Health AG claims that: "You should rather postpone building facilities and work with fewer people, in particular if the outlooks are rather uncertain." Frank Taste admits that his company has lived off its two top-selling products "for a bit too long." However, along with the transition from the second to the third generation, a new entrepreneurial spirit has developed within the company. The two third-generation Taste brothers and their team have successfully launched a new product line, increased export orientation, and introduced an umbrella brand strategy: the first proactive moves after a long period of a reactive competitive posture. The family CEO of Technics AG draws a comparable picture about proactiveness spaced across long intervals. "In 1910 our company was at the forefront of a technological revolution, and in 1947 we introduced another product line, way ahead of our competitors. Today we strive to be proactive by reducing ecological concerns related to the use of our products."

Hence, the firms we examined cannot be considered consistently strong proactive organizations. Taste SA and Health AG, for instance, have moved from pure trading activities to installing their own production facilities, repeatedly increasing their capacities across time. However, in most cases these investments were not undertaken as first moves, but were the result of long-term market screening and observation of competitors' actions. Even though the current management teams of Taste SA, Health AG, and Technics AG seem to display a proactive mindset, it remains unclear to what extent nonoperating family shareholders would support proactive investments associated with large and risky resource commitments. As the family CEO of Health AG points out, family members not involved in firm operations would most likely inhibit a proactive move (e.g., opening overseas production facilities). In a similar way, a family supervisory board member of Technics AG states: "As you know, our non-operating shareholders are rather risk averse. They have what I would call a 'pension fund mentality.' And they have said no to a recent opportunity to acquire a nano-technology company that would have allowed us to enter a market that could become relevant in our field." These cases suggest that family owners not involved in business operations hinder bold proactive moves.

In sum, we contribute to research on proactiveness in family firms with two insights. First, our firms exhibit a dynamic pattern regarding the level of proactiveness over time. They show longer periods of rather low levels of proactiveness, interrupted by phases of carefully selected proactive moves. Most of these firms adopted a wait-and-see posture, waiting for the right moment to leap ahead of the competition. Second, given our findings on family shareholders not involved in firm operations, we suggest that family CEOs willing to be more proactive may be hindered by family ownership structure. More formally stated:

Proposition 4a Proactiveness in long-lived family firms fluctuates over time, with periods of low levels of proactiveness interspersed with carefully selected proactive moves.

Proposition 4b The stronger the influence of family shareholders not involved in the firm's operations, the lower the level of proactiveness in long-lived family firms.

\subsection{Competitive aggressiveness}

Family business research seems to indicate that competitive aggressiveness is of significantly lower relevance in the context of family firms (Martin and Lumpkin 2003; Nordqvist et al. 2008). Eddleston et al. (2008b) suggest that comprehensive strategic decision-making and long-term orientation can be seen as antecedents to competitive aggressiveness and innovativeness. 
Our case analysis reveals that all three firms under investigation display low levels of competitive aggressiveness (Fig. 1). For example, our interviewees voice a strong desire to dominate a market niche, thereby avoiding head-to-head competition and striving to be a "hidden champion" (Simon 1996); with hidden understood not in terms of invisibility due to smaller size but as a competitive posture that avoids direct confrontation. By following a nonaggressive posture, our firms preferred a "live and let live" and "let them do their things" posture. As Norbert Health, CFO of Health AG, points out: "Being aggressive would not fit our company at all. I prefer a differentiation of our company that is based on our basic values and on our tradition as a Swiss family business. We have to be cautious with our outside appearance; we have to avoid aggressiveness and pomposity. We prefer being small but nice-a pearl in the market. The aim is sustainable success and not short-term profit maximization."

In a similar way, the family marketing director of Taste SA claims: "Recently, a competitor tried to increase his market share with a radical change of the product's packaging. However, the customers did not accept the fancy changes, since the product itself remained the same. The resulting damage for the brand and also the company is tremendous. Such aggressive marketing campaigns would never have happened in our company."

We interpret these statements on lower competitive aggressiveness not only in light of the resource constraints these firms face in comparison with the industry giants with which they are competing, but also as a concern for firm reputation. Family managers might be particularly hesitant to be seen as aggressive, since a negative corporate reputation for aggressive firm behavior might negatively affect the reputation of the family and the manager. This is due to identity overlaps between the firm, family, and individual and is reinforced by the inability to leave the family or to easily switch management structures (Dyer and Whetten 2006; Martin and Lumpkin 2003).

Tying back to existing research, we partly support the findings of Martin and Lumpkin (2003) that competitive aggressiveness might be lower for latergeneration family firms. However, we reach beyond their assertion that decreasing competitive aggressiveness across generations may be induced by increasing levels of family orientation. We propose a reputation-based rationale for why competitive aggressiveness should be lower in long-lived family firms. Reputation strengthens over time and is dependent on governance and ownership structures (Rindova and Fombrun 1999). Our three companies have built strong reputations over decades whereby this reputation is supported by stable governance and ownership and structures, and all family members are concerned that aggressive behavior might destroy that image, including negative effects on personal reputation due to overlapping identities (Dyer and Whetten 2006). More formally stated:

Proposition 5 Competitive aggressiveness of longlived family firms decreases over time due to reputation concerns of the controlling family.

\section{Discussion and implications}

We set out to investigate the concept of firm-level corporate entrepreneurship measured through the EO construct in the context of long-lived family firms, given the inconsistent results in the literature about how entrepreneurship should be understood in this specific context (Schulze et al. 2003; Zahra et al. 2004). Through three in-depth case studies of family firms, each between 80 and 175 years old, in which we interviewed 13 family and nonfamily managers, we touch upon the uniqueness of firm-level corporate entrepreneurship that arises from the systemic interaction of individual, family, and firm. With this casebased methodology, we strive to overcome problems associated with the use of single-respondent survey data in entrepreneurship research (Zahra et al. 1999) and address the general lack of attention to lagged effects among the antecedents, performance outcomes, and different forms of corporate entrepreneurship (Dess et al. 2003). We thereby gain several theoretical insights into the manifestation of corporate entrepreneurship in this specific context.

First, and in contrast to the prevailing view in the entrepreneurship field, interviews seem to indicate that our firms exhibit low, or at best medium, levels of the five salient EO dimensions. This partly contradicts the assumption that lower levels of EO should endanger organizational survival and prosperity (e.g., Covin et al. 2006; Dess et al. 2003; Wiklund 2006; Wiklund and Shepherd 2005). Our research 
reveals that the key to generation-spanning success is not dependent on consistently reaching the maximum degree of all EO dimensions. "More is better" does not always seem to be true. To achieve success across generations, continuous adaptation of the company's EO profile seems to be necessary. Accordingly, we claim that generational change has a strong impact on $\mathrm{EO}$, and we provide a dynamic perspective of EO in family firms. The observed contradiction to general EO wisdom might be related to the fact that the EO construct is inherently static, as it is developed and used to measure entrepreneurial behavior at a certain point in time. As such, we add to Zahra et al.'s (1999) reflection on equifinality, which suggests that organizations can utilize different orientations to reach the same objective.

Second, we provide a more fine-grained and somewhat different perspective on several dimensions of EO. Regarding autonomy, we support Nordqvist et al.'s (2008) suggestion to distinguish between external and internal autonomy. More specifically, over time, we find increasing levels of internal autonomy and a consistently high level of external autonomy. Accordingly, we propose that internal autonomy, at least retrospectively, cannot serve as an explanation for the continuing success of these firms and that the constant presence of external autonomy better explains this success. As a consequence, we suggest that long-lived family firms display consistently high levels of external autonomy, whereas internal autonomy increases when later family generations join the firm.

Regarding innovativeness, we expand existing knowledge by finding that the corresponding scale of EO is not perfectly suitable to examine long-lived family firms. While our firms score low on the traditional innovativeness scale that measures new products, markets, and technological processes (Lumpkin and Dess 1996), the interviews revealed high levels of internal and "invisible" innovations such as exploiting existing solutions and the improvement of management systems and governance structures (i.e., internal process redesign). Although these internal innovations also contribute to success, they are not captured by the traditional innovativeness scale of EO. As our interviewees point out, innovativeness fluctuates over time, since innovations must be absorbed and may not be immediately apparent. We add to the calls by researchers to consider the lagged effects of corporate entrepreneurship (Dess et al. 2003) and suggest that the family life cycle has a strong effect on innovativeness. We propose that generational changes can increase the level of internal and external innovativeness in family firms, which is in line with Hoy's (2006) claim that the lifecycle stage of family members is a decisive factor regarding family firm entrepreneurial behavior, and especially innovativeness.

As for risk taking, we propose that risk is multidimensional and suggest extending the risk taking dimension to overcome the fragmentary picture presented by the traditional measure (Naldi et al. 2007; Zahra 2005). Specifically, we propose three different aspects of risk, leading to a more finegrained understanding of this dimension. First, we identify high levels of ownership risk, resulting from increased levels of undiversified wealth tied to the family firm. Second, as a result of heightened ownership risk, we find a lower willingness to take risky business decisions, defined as performance hazard risk. Third, we reveal an aversion to high levels of control risk, measured in terms of leverage. Also, we cannot find support for the claim by Martin and Lumpkin (2003) that the level of risk, in whatever form, decreases as later generations join the firm.

We also add new insights into the proactiveness dimension, with two major findings. First, our firms exhibit a dynamic pattern regarding the level of proactiveness over time, with longer periods of rather low levels of proactiveness interspersed with phases of carefully selected proactive moves. In most cases, these firms adopted a wait-and-see posture, waiting for the right moment to leap ahead of the competition. Second, given our findings on family shareholders not involved in firm operations, we suggest that the strong influence of nonoperating family members can hinder the proactive moves of family CEOs. Our findings might help to reconcile the divergent insights in the literature on the relevance of proactiveness (e.g., Martin and Lumpkin 2003; Nordqvist et al. 2008).

Regarding the competitive aggressiveness dimension, a main outcome of our research is that high levels of competitive aggressiveness do not seem to be a necessary precondition for generation-spanning success, despite the presumably pivotal role of competitive aggressiveness within EO (Lumpkin 
and Dess 1996). While we partly support the argument of Martin and Lumpkin (2003) that competitive aggressiveness decreases in later generations, we suggest that this decrease may be due not only to increasing family orientation, as these authors state, but also to possible negative spillover effects on personal and family reputation.

\subsection{Limitations}

Our research is not without limitations. In our attempt to investigate entrepreneurship in the context of family firms, we follow a "common denominator" approach (Dyer and Handler 1994; Hoy and Verser 1994), that is, examining an element or characteristic held in common. We are aware that this approach is limited in terms of its explicative power. If the goal is to study family businesses through the lens of entrepreneurship, as in our case, then that common denominator will define what actually can and will be studied. However, specific family-related aspects, such as family structures, succession plans, and family harmony, cannot be fully understood through the lens of corporate entrepreneurship or EO. A second possible limitation is the generalizability of our findings, a common criticism of case study research (Punch 2005). However, we see our interpretations and the derived propositions as analytical rather than statistical generalizations derived through rigorous research. Additionally, as our cases all stem from the same cultural background (Switzerland), the applicability of our results to long-lived family firms from other cultures may be limited. Finally, as we extrapolate from our findings to the population of long-lived family firms, we need to address the issue of heterogeneity (e.g., Hall and Nordqvist 2008; Sharma 2003). Given the selection of cases, our findings might be particularly suited to explain entrepreneurial behavior in mid-sized and later-generation family firms. Our considerations might be of less relevance in the context of small and young family firms.

\subsection{Directions for future research}

We suggest several avenues for future research. One possibility is to test both our propositions and our challenging of the implicit assumption regarding EO that "more is better." This could be done with a cross-sectional study, investigating the stable subdimensions of EO (i.e., external autonomy, ownership risk, and control risk) that we have identified in our case studies. To capture the changing EO subdimensions over time, this study could be conducted at two points of time, for example, before and after a younger generation has taken over the family business. Furthermore, we call for additional case study research for further substantiation of our findings. Both the survey(s) and the case studies could take place in different cultural and industrial contexts to further improve the generalizability of our results. There is an opportunity to explore what we might label the "liability of oldness," as opposed to the "liability of newness" (Stinchcombe 1965). Whereas young firms may act aggressively in general (due to newness), more established organizations might challenge their competitors purely to ensure their own market presence, established reputation, and survival (due to oldness). In addition, researchers could consider the question of how the EO profile of long-lived family firms can be transformed over time and which factors support or hinder such attempts. Entrepreneurship researchers might follow our suggestion to rethink the definitions of the autonomy, innovativeness, and risk taking dimensions according to the insights gained in the family business context, which could enrich research in other contexts. Additionally, conducting research in the context of long-established nonfamily firms could lead to valuable insights regarding the extent to which our findings are applicable to nonfamily firms.

\section{Conclusions}

Tying back to our research question, we examined the boundaries of the EO construct when applied in the context of long-lived family firms. Our cases show that these firms have been successful over time, even with moderate or low levels of overall corporate entrepreneurship. To fully capture the patterns of corporate entrepreneurship in family firms and to understand these firms' continuing success, we propose several extensions to the existing EO dimensions. In such a refined EO profile, long-lived family firms seem to display a consistent pattern of entrepreneurship that partly challenges accepted wisdom. 
Thus, we hope to inspire future entrepreneurship and family business scholars with our findings and propositions. In this way, we could fulfill our goal of giving back to the field that has enriched our work.

\section{References}

Aldrich, H. (1999). Organizations evolving. London: Sage.

Aldrich, H. E., \& Cliff, J. E. (2003). The pervasive effects of family on entrepreneurship: Toward a family embeddedness perspective. Journal of Business Venturing, 18(5), 573-596.

Allio, M. K. (2004). Family businesses: Their virtues, vices, and strategic path. Strategy \& Leadership, 32(4), 24-34.

Barringer, B. R., \& Bluedorn, A. C. (1999). The relationship between corporate entrepreneurship and strategic management. Strategic Management Journal, 20(5), 421-444.

Benson, B. (1991). Creating the board of directors: When success demands too much. In C. E. Aronoff \& J. L. Ward (Eds.), Family business sourcebook (pp. 325-333). Detroit: Omnigraphics.

Brockhaus, R. H. S. (1994). Entrepreneurship and family business research: Comparisons, critique, and lessons. Entrepreneurship Theory and Practice, 19(1), 25-38.

Cabrera-Suarez, K., De Saa-Perez, P., \& Garcia-Almeida, D. (2001). The succession process from a resource- and knowledge-based view of the family firm. Family Business Review, 14(1), 37-48.

Chrisman, J. J., Chua, J. H., \& Sharma, P. (2005). Trends and directions in the development of a strategic management theory of the family firm. Entrepreneurship Theory \& Practice, 29(5), 555-575.

Chrisman, J. J., Chua, J. H., \& Steier, L. P. (2002). The influence of national culture and family involvement on entrepreneurial perceptions and performance at the state level. Entrepreneurship Theory \& Practice, 26(4), 113-130.

Chua, J. H., Chrisman, J. J., \& Steier, L. P. (2003). Extending the theoretical horizons of family business research. Entrepreneurship Theory \& Practice, 27(4), 331-338.

Covin, J. G. (1991). Entrepreneurial versus conservative firms: A comparison of strategies and performance. Journal of Management Studies, 28(5), 439-462.

Covin, J. G., Green, K. M., \& Slevin, D. P. (2006). Strategic process effects on the entrepreneurial orientation-sales growth rate relationship. Entrepreneurship Theory \& Practice, 30(1), 57-81.

Covin, J. O., \& Miles, M. P. (1999). Corporate entrepreneurship and the pursuit of competitive advantage. Entrepreneurship Theory \& Practice, 23(3), 47-63.

Covin, J. G., \& Slevin, D. P. (1991). A conceptual model of entrepreneurship as firm behavior. Entrepreneurship Theory and Practice, 16(1), 7-24.

Denzin, N. K., \& Lincoln, Y. S. (2000). Handbook of qualitative research ( $2 \mathrm{nd}$ ed.). Thousand Oaks, CA: Sage.

Dess, G. G., Ireland, R. D., Zahra, S. A., Floyd, S. W., Janney, J. J., \& Lane, P. J. (2003). Emerging issues in corporate entrepreneurship. Journal of Management, 29(3), 351-378.
Dess, G. G., \& Lumpkin, G. T. (2005). The role of EO in stimulating effective corporate entrepreneurship. Academy of Management Executive, 19(1), 147-156.

Dyer, W. G., \& Handler, W. (1994). Entrepreneurship and family business: Exploring the connections. Entrepreneurship Theory and Practice, 19(1), 71-84.

Dyer, W. G., \& Whetten, D. A. (2006). Family firms and social responsibility: Preliminary evidence from the S\&P 500. Entrepreneurship Theory \& Practice, 30(6), 785-802.

Eddleston, K. A., \& Kellermanns, F. W. (2006). Destructive and productive family relationships: A stewardship theory perspective. Journal of Business Venturing, 22(4), 545565.

Eddleston, K. A., Kellermanns, F. W., \& Sarathy, R. (2008a). Resource configuration in family firms: Linking resources, strategic planning and technological opportunities to performance. Journal of Management Studies, 45(1), 26-50.

Eddleston, K., Kellermanns, F. W., \& Zellweger, T. (2008b). Corporate entrepreneurship in family firms: A stewardship perspective. Paper presented at the USASBE, San Antonio.

Eisenhardt, K. M. (1989). Building theories from case study research. Academy of Management Review, 14(4), 532-550.

Gartner, W. B. (1990). What are we talking about when we talk about entrepreneurship? Journal of Business Venturing, 5(1), 15-28.

Gomez-Mejia, L. R., Haynes, K. T., Nunez-Nickel, M., Jacobson, K. J. L., \& Moyano-Fuentes, J. (2007). Socioemotional wealth and business risks in family-controlled firms: Evidence from Spanish olive oil mills. Administrative Science Quarterly, 52(1), 106-137.

Habbershon, T. G., \& Pistrui, J. (2002). Enterprising families domain: Family-influenced ownership groups in pursuit of transgenerational wealth. Family Business Review, 15(3), 223-237.

Habbershon, T. G., Williams, M., \& MacMillan, I. C. (2003). A unified systems perspective of family firm performance. Journal of Business Venturing, 18(4), 451-465.

Hall, A., Melin, L., \& Nordqvist, M. (2001). Entrepreneurship as radical change in the family business: Exploring the role of cultural patterns. Family Business Review, 14(3), 193-208.

Hall, A., \& Nordqvist, M. (2008). Professional management in family businesses: Toward an extended understanding. Family Business Review, 21(1), 51-69.

Hoskisson, R. E., Hitt, M. A., \& Hill, C. W. L. (1991). Managerial risk taking in diversified firms: An evolutionary perspective. Organization Science, 2(3), 296-314.

Hoy, F. (1992). Strategic management and the family firm. In UCLA invited international conference on family business, Los Angeles, CA, USA.

Hoy, F. (2006). The complicating factor of life cycles in corporate venturing. Entrepreneurship Theory \& Practice, 30(6), 831-836.

Hoy, F., \& Verser, T. G. (1994). Emerging business, emerging field: Entrepreneurship and the family firm. Entrepreneurship Theory \& Practice, 19(1), 9-23.

Jennings, D. F., \& Seaman, S. L. (1994). High and low levels of organizational adaptation: An empirical analysis of strategy, structure, and performance. Strategic Management Journal, 15(6), 459-475. 
Kellermanns, F. W., \& Eddleston, K. A. (2006). Corporate entrepreneurship in family firms: A family perspective. Entrepreneurship Theory \& Practice, 30(6), 809-830.

Kreiser, P. M., Marino, L. D., \& Weaver, K. M. (2002). Assessing the psychometric properties of the entrepreneurial orientation scale: A multi-country analysis. Entrepreneurship Theory and Practice, 26(4), 71-94.

Kuratko, D. F., Ireland, R. D., Covin, J. G., \& Hornsby, J. S. (2005). A model of middle-level manager's entrepreneurial behavior. Entrepreneurship Theory \& Practice, 29(6), 699-716.

Lieberman, M., \& Montgomery, D. (1988). First-mover advantages. Strategic Management Journal, 9(Summer special issue), 41-58.

Low, M. B., \& MacMillan, I. C. (1988). Entrepreneurship: Past research and future challenges. Journal of Management, 14(2), 139-161.

Lumpkin, G. T., \& Dess, G. G. (1996). Clarifying the entrepreneurial orientation construct and linking it to performance. Academy of Management Review, 21(1), 135-172.

Lumpkin, G. T., \& Dess, G. G. (2001). Linking two dimensions of entrepreneurial orientation to firm performance: The moderating role of environment and industry life cycle. Journal of Business Venturing, 16(5), 429-451.

Lyon, D. W., Lumpkin, G. T., \& Dess, G. G. (2000). Enhancing entrepreneurial orientation research: Operationalizing and measuring a key strategic decision making process. Journal of Management, 26(5), 1055-1085.

Martin, L., \& Lumpkin, T. (2003). From EO to "family orientation": Generational differences in the management of family businesses. In 22nd Babson College entrepreneurship research conference. Babson College.

McCann, J. E., Leon-Guerrero, A. Y., \& Haley, J. D., Jr. (2001). Strategic goals and practices of innovative family businesses. Journal of Small Business Management, 39(1), 50-59.

Miller, D. (1983). The correlates of entrepreneurship in three types of firms. Management Science, 29(7), 770-791.

Miller, D., \& Friesen, P. H. (1978). Archetypes of strategy formulation. Management Science, 24(9), 921-933.

Miller, D., Le Breton-Miller, I., \& Scholnick, B. (2008). Stewardship vs. stagnation: An empirical comparison of small family and non-family businesses. Journal of Management Studies, 45(1), 51-78.

Mishra, C. S., \& McConaughy, D. L. (1999). Founding family control and capital structure: The risk of loss of control and the aversion to debt. Entrepreneurship Theory \& Practice, 23(4), 53-64.

Morck, R., \& Yeung, B. (2003). Agency problems in large family business groups. Entrepreneurship Theory \& Practice, 27(4), 367-382.

Morris, M. H. (1998). Entrepreneurial intensity: Sustainable advantages for individuals, organizations, and societies. Westport, CT: Quorum Books.

Naldi, L., Nordqvist, M., Sjöberg, K., \& Wiklund, J. (2007). Entrepreneurial orientation, risk taking, and performance in family firms. Family Business Review, 20(1), 33-47.

Nordqvist, M., Habbershon, T. G., \& Melin, L. (2008). Transgenerational entrepreneurship: Exploring EO in family firms. In H. Landström, H. Crijns, \& E. Laveren (Eds.), Entrepreneurship, sustainable growth and performance: Frontiers in European entrepreneurship research (pp. 93-116). Cheltenham: Edward Elgar.

Poza, E. J., Alfred, T., \& Maheshwari, A. (1997). Stakeholder perceptions of culture and management practices in family and family firms. Family Business Review, 10(2), 135155.

Punch, K. F. (2005). Introduction to social research-Quantitative \& qualitative approaches. London: Sage.

Rauch, A., Wiklund, J., Lumpkin, G. T., \& Frese, M. (2009). Entrepreneurial orientation and business performance: An assessment of past research and suggestions for the future. Entrepreneurship Theory and Practice, 33(3), 761-787.

Rindova, V. P., \& Fombrun, C. J. (1999). Constructing competitive advantage: The role of firm-constituent interactions. Strategic Management Journal, 20(8), 691-710.

Rogoff, E. G., \& Heck, R. K. Z. (2003). Evolving research in entrepreneurship and family business: Recognizing family as the oxygen that feeds the fire of entrepreneurship. Journal of Business Venturing, 18(5), 559-566.

Salvato, C. (2004). Predictors of entrepreneurship in family firms. Journal of Private Equity, 7(3), 68-76.

Schein, E. H. (1983). The role of the founder in creating organizational culture. Organizational Dynamics, 12(1), 13-28.

Schendel, D., \& Hitt, M. A. (2007). Comments from the editors. Strategic Entrepreneurship Journal, 1(1-2), 1-6.

Schulze, W. S., Lubatkin, M. H., \& Dino, R. N. (2003). Toward a theory of agency and altruism in family firms. Journal of Business Venturing, 18(4), 473-490.

Schumpeter, J. A. (1934). The theory of economic development. Cambridge, MA: Harvard University Press.

Schumpeter, J. A. (1942). Capitalism, socialism, and democracy. New York: Harper \& Broth.

Sharma, P. (2003). Stakeholder mapping technique: Toward the development of a family firm typology. Paper presented at the Academy of Management Meetings, Denver, CO.

Sharma, P. (2004). An overview of the field of family business studies: Current status and directions for the future. Family Business Review, 17(1), 1-36.

Shepherd, D., \& Zahra, S. A. (2003). From conservatism to entrepreneurialism: The case of Swedish family firms. Boulder, CO: University of Colorado.

Simon, H. (1996). Hidden champions: Lessons from 500 of the world's best unknown companies. Boston, MA: Harvard Business School Press.

Spinelli, S. J., \& Hunt, J. (2000). Leadership and entrepreneurial behavior in the next generation of self-described family owned businesses. Paper presented at the BCERC, Babson College, USA.

Stevenson, H. H., \& Jarillo, J. C. (1990). A paradigm of entrepreneurship: Entrepreneurial management. Strategic Management Journal, 11(4), 17-27.

Stinchcombe, A. L. (1965). Social structure and organizations. In J. G. March (Ed.), Handbook of organizations (pp. 142-193). Chicago: Rand McNally.

Whiteside, M. F., \& Brown, F. H. (1991). Drawbacks of a dual systems approach to family firms: Can we expand our thinking? Family Business Review, 4(4), 383-395.

Wiklund, J. (2006). The sustainability of the entrepreneurial orientation-performance relationship. In P. Davidsson, F. Delmar, \& J. Wiklund (Eds.), Entrepreneurship and the 
growth of firms (pp. 141-155). Northampton, MA: Edward Elgar.

Wiklund, J., \& Shepherd, D. (2005). Entrepreneurial orientation and small business performance: A configurational approach. Journal of Business Venturing, 20(1), 71-91.

Yin, R. K. (1994). Case study research: Design and methods (2nd ed.). Thousand Oaks, CA: Sage.

Yin, R. K. (1998). The abridged version of case study research: Design and method. In L. Bickman \& D. J. Rog (Eds.), Handbook of applied social research methods (pp. 229260). Thousand Oaks, CA: Sage.

Zahra, S. A. (1995). Corporate entrepreneurship and financial performance: The case of management leveraged buyouts. Journal of Business Venturing, 10(3), 225-247.

Zahra, S. A. (1996). Governance, ownership, and corporate entrepreneurship: The moderating impact of industry technological opportunities. Academy of Management Journal, 39(6), 1713-1735.

Zahra, S. A. (2005). Entrepreneurial risk taking in family firms. Family Business Review, 18(1), 23-40.
Zahra, S. A., \& Covin, J. G. (1995). Contextual influences on the corporate entrepreneurship-performance relationship: A longitudinal analysis. Journal of Business Venturing, 10(1), 43-58.

Zahra, S. A., Hayton, J. C., \& Salvato, C. (2004). Entrepreneurship in family vs. non-family firms: A resource-based analysis of the effect of organizational culture. Entrepreneurship Theory \& Practice, 28(4), 363-381.

Zahra, S. A., Jennings, D. F., \& Kuratko, D. F. (1999). Guest editorial: Corporate entrepreneurship in a global economy. Entrepreneurship Theory \& Practice, 24(1), 7-9.

Zahra, S. A., Neubaum, D. O., \& Huse, M. (2000). Entrepreneurship in medium-size companies: Exploring the effects of ownership and governance systems. Journal of Management, 26(5), 947-976.

Zahra, S. A., \& Sharma, P. (2004). Family business research: A strategic reflection. Family Business Review, 17(4), 331-346.

Zellweger, T. M. (2007). Time horizon, costs of equity capital, and generic investment strategies of firms. Family Business Review, 20(1), 1-15. 